Available online on 15.07.2017 at http://iddtonline.info
Journal Of Drug Delivery and Therapeutics
Open Access to Pharmaceutical and Medical Research
(2011-17, publisher and licensee JDDT, This is an Open Access article which permits unrestricted
noncommercial use, provided the original work is properly cited

Open $\odot$ Access

Research Article

\title{
VALIDATED COLORIMETRIC METHODS FOR THE ESTIMATION OF TENELIGLIPTIN IN TABLETS
}

\author{
Sunitha PG*, Karthikeyan R, Ranjith Kumar B, Muniyappan S \\ Department of Pharmaceutical Chemistry, College of Pharmacy, Madras Medical College, Chennai-600 003, Tamil Nadu, India
}

\begin{abstract}
Two simple sensitive and precise methods A and B were developed for the estimation of teneligliptin in bulk drug as well as in pharmaceutical dosage form. Method A is based on the formation of a red colored chromogen by reaction of teneligliptin with potassium thiocyanate in presence of ferric chloride, which has an absorption maximum at 554nm. Method B is based on the formation of an orange colored complex by complexation reaction of teneligliptin with 2, 2'- bipyridyl in the presence of ferric chloride which has an absorption maximum at $421 \mathrm{~nm}$. The proposed methods are statistically validated and found to be useful for the routine determination of teneligliptin in tablets.
\end{abstract}

Keywords: Teneligliptin, Colorimetry, Tablets, Validation

Article Info: Received 17 May, 2017; Review Completed 10 July, 2017; Accepted 10 July, 2017; Available online 15 July, 2017

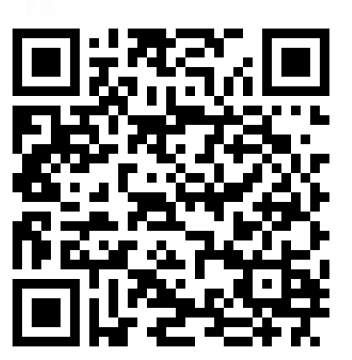

Cite this article as:

Sunitha PG, Karthikeyan R, Ranjith kumar B, Muniyappan S, Validated colorimetric methods for the estimation of Teneligliptin in tablets, Journal of Drug Delivery and Therapeutics. 2017; 7(4):38-40

DOI: http://dx.doi.org/10.22270/jddt.v7i4.1467

${ }^{*}$ Address for Correspondence

Sunitha PG, Department of Pharmaceutical Chemistry, College of Pharmacy, Madras Medical College, Chennai-600 003, Tamil Nadu, India E-mail: sunitha.srm@gmail.com

\section{INTRODUCTION}

Teneligliptin (TNG) is used to help control blood sugar levels in patients affected by type -2 Diabetes ${ }^{1,2}$. Teneligliptin works by inhibiting the activity of an enzyme known as DPP-4. This enzyme is responsible for degrading ingredients such as GLP-1(Glucagon-like peptide 1), which are needed by the body to control blood sugar. Blocking the action of DPP-4 leads to increase in GLP-1 levels. GLP-1 helps to increase the release of insulin, which in turn lower blood glucose levels, thereby making this medicine effective in controlling type-2 diabetes ${ }^{3,4}$.

Chemically it is [(2S, 4S)-4-[4-(3-Methyl-1-phenyl-1Hpyrazol-5-yl)-1-piperazinyl]-2-pyrrolidinyl]-3-thiazolidinyl methanone hydrobromide . 5 The available methods for analysis of this drug in biological fluids and pharmaceutical products are RP-HPLC method ${ }^{6,7}$, LC-
MS method ${ }^{8}$ and HPTLC method. ${ }^{9}$ The present work deals with the estimation of TNG in tablets by visible spectrophotometric methods. In Method A, TNG reacts with potassium thiocyanate and ferric chloride to form a red chromogen, which absorbs intensively at $554 \mathrm{~nm}$. In method B, TNG forms an orange coloured complex with 2, 2'- bipyridyl and ferric chloride which exhibited $\lambda_{\max }$ at $421 \mathrm{~nm}$. The method is alternative and comparable in specificity and accuracy to chromatography methods, which although highly specific and accurate, are more time consuming, performed in several steps and are rather expensive.

\section{MATERIALS AND METHODS}

Instrumentation: All spectral and absorbance measurements were made on UV-Vis Spectrophotometer $-1900 s$. 


\section{Reagents:}

1. Potassium thiocyanate $(2 \% \mathrm{w} / \mathrm{v})$

2. Ethanol $(95 \% \mathrm{w} / \mathrm{v})$

3. 2, 2'Bipyridyl $(0.1 \% \mathrm{w} / \mathrm{v})$

4. Ferric chloride $(5 \% \mathrm{w} / \mathrm{v})$

All reagents used were of analytical grade.

\section{Preparation of standard solution:}

A $1 \mathrm{mg} / \mathrm{ml}$ stock solution of TNG was prepared by dissolving $100 \mathrm{mg}$ of drug in $100 \mathrm{ml}$ of ethanol.

\section{Sample preparation:}

Twenty tablets were weighed and powdered. A quantity equivalent to $100 \mathrm{mgof}$ TNG was weighed accurately, transferred to a beaker, dissolved in ethanol, filtered through whatmann filter paper No. 1 into a $25 \mathrm{ml}$ volumetric flask and made up to volume with ethanol to get a concentration of $1 \mathrm{mg} / \mathrm{ml}$.

\section{Assay:}

\section{Method A:}

Appropriate aliquots of TNG were pipetted out into a series of $25 \mathrm{ml}$ volumetric flasks. To each flask $2 \mathrm{ml}$ of potassium thiocyanate and $2 \mathrm{ml}$ ferric chloride reagent were added, mixed thoroughly and made up to volume with ethanol. The $\lambda_{\max }$ of the red coloured chromogen was found to be $554 \mathrm{~nm}$ (Figure-1). The absorbance of the red coloured chromogen was measured at $554 \mathrm{~nm}$ against the reagent blank. The red chromogen was stable for more than 3 hours. The analytical curve was constructed by plotting concentration versus absorbance.

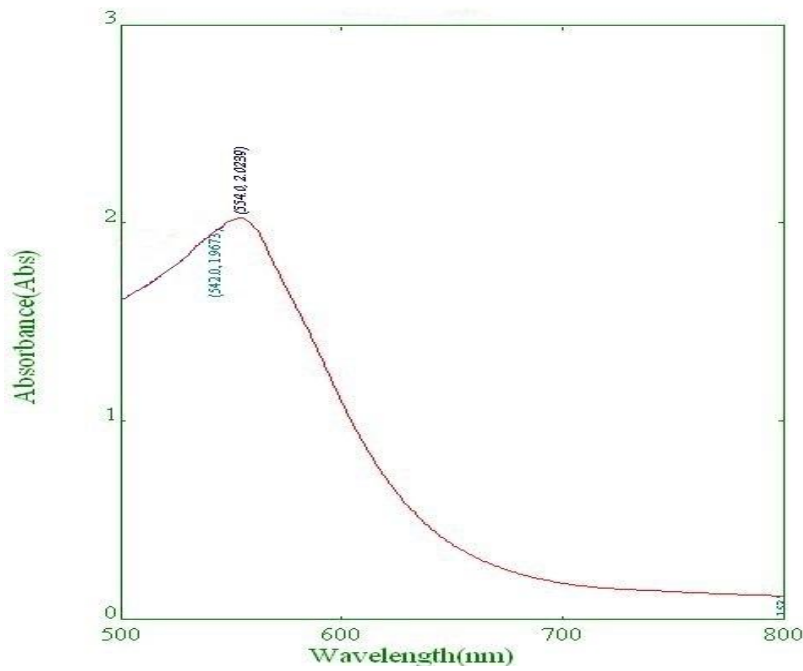

Figure 1: $\lambda_{\max }$ of the red chromogen by Method A

\section{Method B:}

Appropriate aliquots of TNG were pipetted out into a series of $25 \mathrm{ml}$ volumetric flasks. To each flask $2 \mathrm{ml}$ of ferric chloride (5\% w/v) and $3 \mathrm{ml}$ of 2,2'bipyridyl $(0.1 \%$ w/v) were added, heated on a boiling water bath for 15 minutes, cooled and then made up to volume with ethanol. The $\lambda_{\max }$ of the orange coloured chromogen was found to be $421 \mathrm{~nm}$ (Figure-2). The absorbance of the orange coloured chromogen was measured at $421 \mathrm{~nm}$ against the reagent blank. The amount of TNG was computed from the calibration curve obtained by plotting concentration versus absorbance.

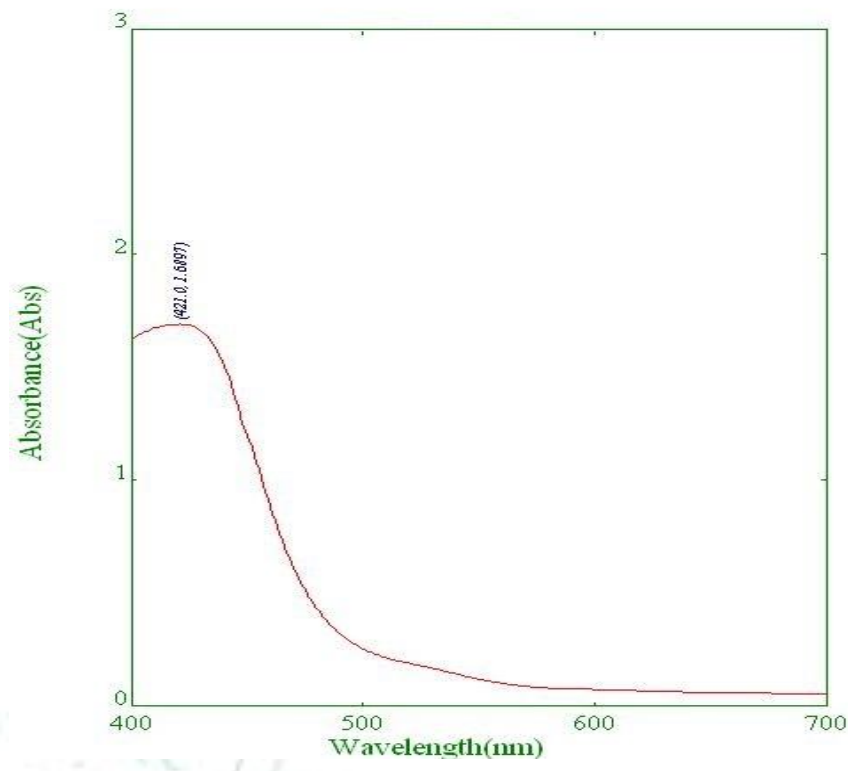

Figure 2: $\lambda_{\max }$ of the orange chromogen by Method B

\section{Sample Analysis:}

Pharmaceutical formulation of TNG was successfully analyzed by the proposed methods. Appropriate aliquots were subjected to the above methods and the amount of the TNG was determined from the calibration curves. The results of sample analysis are furnished in table- 2 .

\section{RESULTS AND DISCUSSION}

The optical characteristics such as absorption maxima, Beer's law limits, Molar absorptivity and Sandell's sensitivity are furnished in table-1. The regression characteristics like slope (b), intercept(a), correlation coefficient(r), percent relative standard deviation (\%RSD) and standard error (SE) obtained from different concentrations were calculated and the results are summarized in table-1.

To study the accuracy and reproducibility of the proposed methods, recovery experiments were carried out by adding a known amount of drug to pre-analyzed sample and the percentage recovery was calculated. The results are furnished in table-2.The results indicate that there are no interference of other ingredients present in the formulation. Thus, the proposed methods are simple, sensitive, precise, accurate and reproducible and useful for the routine determination of TNG in bulk drug and its pharmaceutical dosage form.

\section{ACKNOWLEDGEMENTS}

We are thankful to the Department of Pharmaceutical Chemistry, Madras Medical College, Chennai-03, for providing the instrumentation and laboratory facilities. 
Table 1: Optical characteristics, Precision and Accuracy of the proposed methods

\begin{tabular}{|l|l|l|}
\hline Parameter & Method A & Method B \\
\hline$\lambda \max (\mathrm{nm})$ & $554 \mathrm{~nm}$ & $421 \mathrm{~nm}$ \\
\hline Beer's law limit( $\mu \mathrm{g} / \mathrm{ml})$ & $0.1-0.6$ & $0.2-1.6$ \\
\hline Molar absorptivity $(\mathrm{Lmol}-1 \mathrm{~cm}-1)$ & $40.61 \times 10^{3}$ & $43.03 \times 10^{3}$ \\
\hline Sandell's sensitivity $\left(\mu \mathrm{g} / \mathrm{cm}^{2} / 0.001\right.$ absorbance unit) & 0.01786 & 0.019916 \\
\hline Regression equation(*y) & 0.76735 \\
\hline Slope(b) & 0.13714 & 0.003134 \\
\hline Intercept(a) & -0.08413 & 0.9941 \\
\hline Correlation co-efficient $(\mathrm{r})$ & 0.9999 & 0.078 \\
\hline \% RSD & 0.144 & 0.171 \\
\hline Standard error(SE) & 0.0177 & \\
\hline
\end{tabular}

Table 2: Assay and recovery of TNG in the dosage form (tablets)

\begin{tabular}{|c|c|c|c|}
\hline Method & Labelled amount $(\mathrm{mg})$ & Amount obtained $(\mathrm{mg}) *$ & Percentage recovery** \\
\hline A & 20.00 & 19.95 & 100.01 \\
\hline B & 20.00 & 20.24 & 99.99 \\
\hline
\end{tabular}

*Average of six determinations $* *$ Average of three determinations

\section{REFERENCES}

1. The Merck Index, An encyclopaedia of chemical drugs \& biologicals. ed13, Merck research laboratories division of MERCK \& CO., INC; 2001:P. 1703.

2. Martindale, the complete drug reference. ed 37, Vol. A. London, Pharmaceutical press; 2011: P. 551.

3. Tripathy KD. Essentials of Medical Pharmacology. Ed 6, Jaypee brothers Medical Publishers; 2010:P.172, 402,404.

4. Shanbhag T, Shenoy S. Pharmacology prepared manual for under graduates. ed 2, Reed Elsevier India Private limited; 2015:P.191, 196.

5. Indian Pharmacopoeia 2010, Vol 11l, ed 6, Ghaziabad, Indian Pharmacopoeia Commission. P.2242.

6. Chitlange SS, Rawat DG, Chandani S, Estimation of Antidiabetic Teneligliptin hydrobromide hydrate by RP-HPLC and Derivative Spectroscopy method, Indo American Journal of Pharmaceutical Research,2016; 6(7):P.6144-6153
7. Luhar SV, Pandya KR, Jani GK and Sachin Narkhed B. Simultaneous Estimation of Teneligliptin hydrobromide hydrate and its degradation product by RP-HPLC, Journal of Pharmaceutical Science and Bioscientific Research,2016; 6(3):254-261.

8. Chunduri BRH, Dannana GS, Development and validation of LC-MS/MS method for quantification of teneligliptin in human plasma and its application to a pharmacokinetic study, World Journal of Pharmacy and Pharmaceutical Sciences, 2016; 5(5):838-850.

9. Bakshi M, Singh S, Development of validated StabilityIndicating Assay Methods-Critical Review, Journal of Pharmaceutical and Biomedical Analysis, 2002; 28:10111040. 